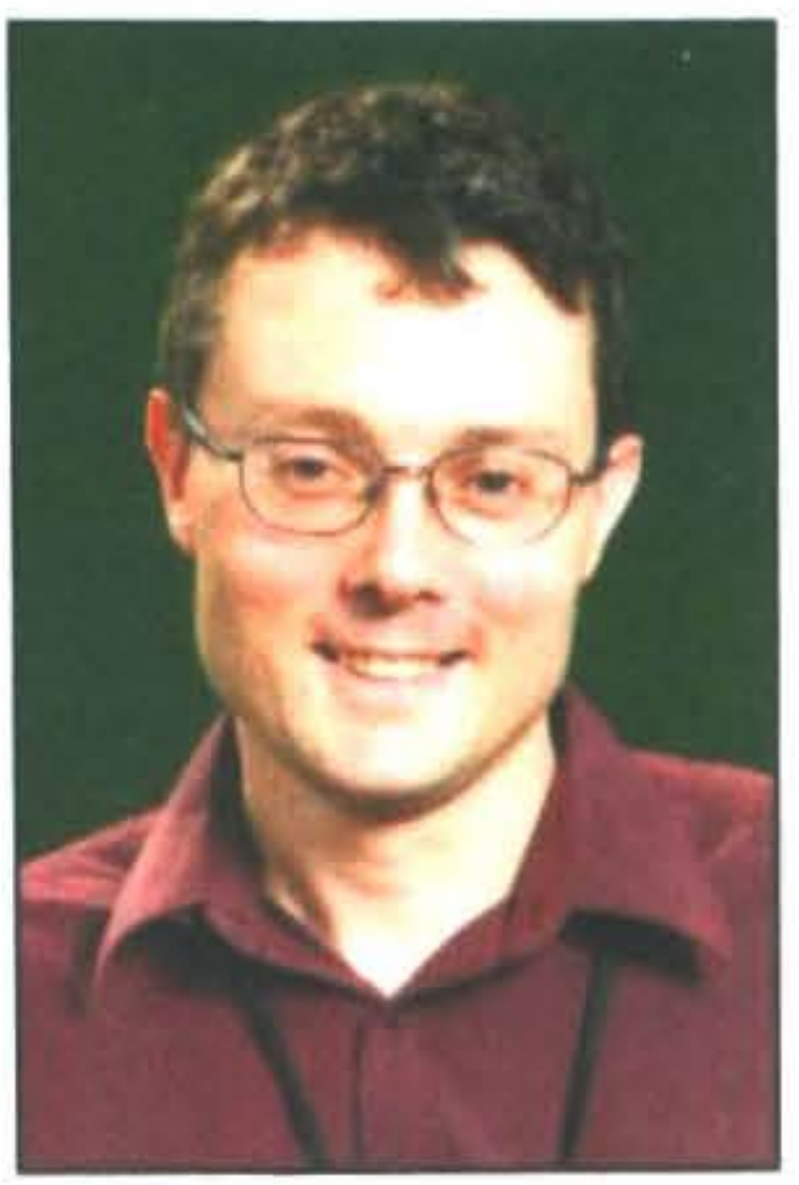

\title{
INTERGENERATIONAL ECONOMIC MOBILITY IN \\ NEW ZEALAND
}

\author{
Matthew Gibbons
}

New Zealand Treasury

This paper. which briefly summarises recent research by Treasury, tentatively quantifies intergenerational economic mobility in New Zealand using income data from a cohort study of people born in Dunedin in 1972-1973, and occupation data from the 1996 Election Study's post-election survey. The intergenerational income elasticity point estimate for all Dunedin Study participants was .26 when using fathers' incomes to explain children's incomes, with the $95 \%$ confidence interval stretching from.14 to 39 . Even with controls for the gender of participants and their father's age, the proportion of variance explained was only 13\%. For the nation-wide Election Study the point estimate for the effect of father's socio-economic status (SES) on the SES of respondents was 20 for respondents aged 25 years and older, with a 95\% confidence interval of .16 to .24. However, father's SES and the age and gender of respondents explained only 5\% of the variance in respondents' SES. We have to be cautious when interpreting our results because both datasets contain proportionately fewer Mãori and Pacific peoples than the New Zealand population, the Election Study data is now almost 13 years old, and the Dunedin Study participants have not reached their peak earning years. Our intergenerational income mobility estimate for New Zealand has wide confidence intervals, while confidence intervals for estimates of intergenerational occupational mobility are not available for most countries. As a result, we reached few firm conclusions about New Zealand's relative position compared to other countries.

\section{Introduction}

Intergenerational mobility research has often estimated the relationship between the economic situation of parents and the economic situation of their children as adults. This paper tentatively tests the relationship in New Zealand between parents' economic situation and the subsequent economic situation of their grownup children using two different model specifications and datasets.

Treasury is interested in understanding how intergenerational mobility affects equality of opportunity, skills development, economic efficiency, productivity, and living standards, realising that high rates of intergenerational mobility are not strictly necessary for achieving progress across all those domains. Low intergenerational mobility can imply that, because of their backgrounds, people are unable to fully develop and use their skills and abilities. As well as signalling low equality of opportunity, this would constitute an inefficient use of a country's human capital (OECD, 2008, p. 3). Conversely, some policies that facilitate skill development and productivity could feasibly lower observed rates of intergenerational mobility and vice versa. For example, expanding tertiary education provision in Britain during the 1960s and 1970s boosted aggregate skills and education levels, but the greatest growth in participation rates was initially among those from better-off families (Jo Blanden, Gregg, \& Machin. 2005, p. 12; Jo Blanden \& Machin, 2007, pp. 15, 19).
We therefore need to be cautious in interpreting what measures of intergenerational mobility may mean for economic progress.

A country's economy undoubtedly benefits when all parents invest time, emotional commitment, and money in their children. Many parents are also supportive if their children aspire to have a similar career to themselves, or if their children want to work in a family business (d'Addio, 2007, p. 11; Roemer, 2004, p. 55). Nevertheless, policies that aim to improve the aspirations, preferences, and skills of those from disadvantaged home environments can sometimes enhance intergenerational mobility and arguably economic growth (d'Addio, 2007, p. 11).

Studying intergenerational economic mobility in New Zealand can shed light on the opportunity New Zealanders have to advance themselves, relative to the economic position of their parents, compared to people in other developed countries. The level of intergenerational mobility is an important measure of the economic openness of a society and of the level of opportunity, although generational mobility is by no means the only measure of these goals (Corak, 2006, p. 12; d'Addio, 2007 , p. 12). Policies to increase intergenerational mobility may sometimes also affect the achievement of other policy objectives, such as individual freedom, making specifying an ideal level difficult (Roemer, 2004, p. 51). 
While there have been a growing number of overseas studies of intergenerational mobility (Corak, 2006), the literature on this topic for New Zealand is very limited. This paper first outlines the methods used by economists to study intergenerational mobility. Income and occupational intergenerational mobility rates in New Zealand are then quantified using two different datasets. These results enable us to cautiously compare rates of intergenerational mobility in New Zealand to those in other developed countries.'

\section{Calculating intergenerational mobility}

Economists have usually studied intergenerational mobility by examining the extent to which a person's childhood economic circumstances predict their adult economic circumstances. The following model estimates intergenerational income mobility:

$$
\ln \left(Y_{i, t}\right)=\alpha+\beta \ln \left(Y_{i, t-1}\right)+\gamma Z_{i, t}+\varepsilon_{i, t}
$$

where:

$\ln \left(Y_{i, t}\right)=$ a natural $\log$ of an individual's permanent income when they have grown up (or a proxy).

$i=$ the family to which children and parents belong

$t=a n$ index of generations

$\alpha=$ the constant

$\beta=$ the intergenerational income elasticity (the marginal effect of a $1 \%$ change in parental income)

$\ln \left(Y_{i, t-1}\right)=$ a natural log of parents' income (usually just of fathers) when their children were growing up

$Z_{i, t}=$ other variables that may feasibly affect incomes.

$\varepsilon=\mathrm{a}$ random error term.

The intergenerational income elasticity ( $\beta$ value) quantifies intergenerational mobility by estimating the effect of a change in the income of a person's parents on their own income as an adult. Assuming that everything else is constant, higher estimates of the intergenerational income elasticity imply larger parental income effects on the incomes of their children and lower intergenerational mobility. A positive intergenerational income elasticity implies that children from higher income families on average grow up to earn more than children from lower income families (holding any factors constant according to model specification).

Demanding data requirements make accurately calculating intergenerational income mobility difficult. Unfortunately relatively few studies have collected data on people's economic circumstances for prolonged periods (Corak, 2006, p. 6). Accurately measuring people's economic situation is also often difficult as their income may vary from year to year. A person's type of work also affects how their income changes as they become older, with some groups of workers reaching their peak earning years earlier than other workers. Higher and more accurate intergenerational mobility results usually occur when a large number of income measurements from peak-earning years are available. As a result, estimates of intergenerational mobility are "highly sensitive" to the number of income measurements available, and the age at which earnings are observed (Haider \& Solon, 2006, p. 1309; Jäntti, et al., 2006, pp. 3, 20). The rate of intergenerational income mobility in some countries is therefore uncertain and widely debated, and there are still no estimates available for many developed countries (OECD, 2008, p. 4).

\section{The New Zealand data}

Data to test income and occupational intergenerational mobility in New Zealand came from two internationally recognized studies: the Dunedin Multidisciplinary Health and Development Study; and the New Zealand Election Study. The Dunedin Study is a cohort study of 1,037 children born between April 1972 and March 1973 in Dunedin. When the participants were born, Dunedin had the fourth biggest population of any New Zealand metropolitan centre. The study included children from a full range of backgrounds (Silva \& McCann, 1996, pp. 11-13). Health outcomes for the participants at age 26 were usually not statistically different to those of other New Zealanders, but the study is under-representative of Māori and Pacific peoples (Poulton, et al., 2006, pp. 1, 9). The Pearson's correlation between childhood socioeconomic status (SES) and adult SES was .32 (Melchior, Moffitt, Milne, Poulton, \& Caspi, 2007, p. 969). ${ }^{2}$

We used data on parents' incomes when the participants were aged 13 and 15 , together with data on the incomes of participants from their most recent assessment at age 32. When data on the incomes of participants' parents was collected, the average age of mothers was 40 and the average age of fathers was 42 .

At age $32,94 \%$ of those assessed by the study at age three were still participating. We lose some additional cases, mainly because of non-reporting of fathers' incomes. This reflects the intensely personal nature of information about people's income, with the pattern of results suggesting some women felt unable to accurately state their partner's income. It is not possible to check whether the relationship between father's income and the income of participants (at age 32) for participants with missing father's income data is different than for those whose father's income was reported. We also lose cases when female participants (who almost invariably stated that they had partners who were earning) reported zero income.

Intergenerational mobility was also measured using occupation data from the large 1996 New Zealand Election Study dataset. ${ }^{3}$ In 1996, the Election Study's nation-wide post-election survey asked respondents what their occupation was and what their parents' occupations had been when the respondent was aged about 14. It was not until 2008 that the election study again asked respondents about their parents' occupations, and the 2008 data is not yet available. 
The Election Study's sample frame was people on the electoral roll. In 1996, $91.6 \%$ of eligible voters were enrolled and $88 \%$ of enrolled electors voted (New Zealand Post, 1997, section 80). The Election Study's postal response rate was $55.7 \%$ (4,118 respondents). Groups that are less likely to be on the electoral roll, vote, and answer surveys, include those who move frequently, young people, people who are travelling overseas, Māori, and some ethnic groups (Electoral Law Committee, 1998, pp. 26-33; Vowles, 2002, pp. 99-193). The Election Study weight ensures that the data matches voting behaviour, but the data does not always perfectly mirror the characteristics of New Zealand's population. As a result, caution is necessary when interpreting the results.

People's occupation determined their SES score. The average income of people in different occupations in the 1996 census, together with data on their educational qualifications and survey data on the value of goods they consumed, was used to calculate the SES of occupations (Davis, Jenkin, \& Coope, 2003, pp. 12-16). Since occupation is an excellent indicator of permanent income (the average income than an individual expects to receive over their lifetime), data on SES has frequently been used to calculate intergenerational mobility (Jo Blanden, 2008 , 16). While people's SES is not the same as their income, the SES scores correlate with health and economic outcomes (Davis, et al., 2003, p. 11). ${ }^{4}$

\section{The Dunedin Study results}

The results in this section relate to individuals who were born in Dunedin between April 1972 and March 1973. Table 1 shows intergenerational income elasticity estimates and confidence intervals for five models of intergenerational mobility. ${ }^{5}$ The first model tested how well the incomes of fathers explained the incomes of male participants, with the standard controls of father's age and father's age squared (Solon, 1992, p. 399). The intergenerational income elasticity for model one was .29. This implies that if an average man's father earned 1\% more, he himself would be estimated to earn .29\% more annually at age 32 . The confidence intervals for the parameter of .13 and .45 indicate the range of values that are likely to contain the true parameter value in $95 \%$ of identical models generated from repeated random samples. The age controls are not statistically significant for any model.

Our estimate is very similar to Andrews and Leigh's recent calculation of an intergenerational income elasticity of .25 for New Zealand men aged between 25 and 54. They used 1999 survey data on respondents' recall of their fathers' occupations to impute incomes (Andrews \& Leigh, 2008, p. 13). Andrews and Leigh's $95 \%$ confidence intervals were slightly wider than for the Dunedin Study data, however, as they stretched between .04 and .46

The Dunedin results are easier to understand by considering an example. When the participants were in their teens the average income of fathers in the Dunedin
Study was about $\$ 48,000$ in 2008 values, while the level of income imputed for fathers in the top income group was approximately $\$ 81,000$. Suppose a man from Dunedin had grown up with a father who was in the top income group and who was the average age of 41 when they were 13. The intergenerational income elasticity for model one of .29 implies that this man would, on average, earn approximately $\$ 11,000$ more annually at age 32 than another man, with the same aged father, whose father had been in the average income group. ${ }^{6}$ Because of the wide confidence intervals, however, we have to be very cautious. Model one explained only $3.8 \%$ of the variance in the incomes of men (see the adjusted $\mathrm{R}^{2}$ line in Table 1 ), indicating that a wide range of other factors influence participants' incomes.

The estimated intergenerational income elasticity for women was .22 (see model two), but the probability of .14 associated with the $\mathrm{F}$ score indicates that the explanatory variables did not reliably predict the adult income of female Dunedin Study members. ${ }^{7}$ Model two also explained just $1.5 \%$ of the variance in women's incomes. Measuring intergenerational mobility for women in the Dunedin Study is difficult because the labour force participation of some women was limited by the time they were spending looking after children. At age $32,13.4 \%$ of women and $1.1 \%$ of men in the Dunedin Study were out of the workforce because they were homemakers or beneficiaries. The overlapping confidence intervals show that the difference between the intergenerational income elasticities for men and women is not statistically significant.

For the third model we included all participants and dropped the statistically insignificant variables for the age of fathers. For all participants we got an intergenerational income elasticity of .26 , with the confidence intervals stretching between .14 and .39. Although the proportion of variance explained is higher than for the first two models, this has occurred because we have pooled men and women. Although the single-gender models allowed for a gender difference in the effect of father's income, they isolated the "within gender" variation in incomes and therefore did not attempt to explain the "between gender" variation. Model 3 does this by including a control for the tendency for men to earn more than women. Tests of whether the effect of father's income differed for men and women indicated no significant difference, so no interaction term is included in the model. The pooled model without the gender control explains only $1.4 \%$ of the variance in incomes, which implies that the gender control explains more of the variance in incomes than fathers' income alone.

Most overseas studies of intergenerational income mobility have used the income of participants' fathers as the main explanatory variable. This is because the incomes of women tend to fluctuate more. However, studying the combined effect of both parents' incomes arguably produces a richer picture of intergenerational mobility (Corak, 2006, pp. 9, 11). In model four, the relationship between parents' combined income and the income of their child or children was therefore tested. The 
intergenerational income elasticity estimate for model four of .27 is very similar to the .26 result for model three, showing that changing the explanatory variable had very little effect. This is not entirely surprising: when participants were 13 and 15 on average fathers received $75 \%$ of the total income of Dunedin Study families. There was a .20 correlation between the unlogged incomes of mothers and of fathers, indicating assortative coupling.

Table 1: Intergenerational Income Elasticity Results for Dunedin Study Participants at age 32

\begin{tabular}{|c|c|c|c|c|c|}
\hline & $\begin{array}{l}\text { Model 1: } \\
\text { Income of all } \\
\text { male } \\
\text { participants } \\
\text { irrespective of } \\
\text { country }\end{array}$ & $\begin{array}{l}\text { Model 2: } \\
\text { Income of all } \\
\text { female } \\
\text { participants } \\
\text { irrespective of } \\
\text { country }\end{array}$ & $\begin{array}{l}\text { Model 3: } \\
\text { Income of all } \\
\text { participants } \\
\text { irrespective of } \\
\text { country }\end{array}$ & $\begin{array}{l}\text { Model 4: } \\
\text { Income of all } \\
\text { participants } \\
\text { with parents' } \\
\text { income as } \\
\text { explanatory } \\
\text { variable }\end{array}$ & $\begin{array}{l}\text { Model 5: } \\
\text { Income of all } \\
\text { participants } \\
\text { with controls } \\
\text { for education }\end{array}$ \\
\hline Constant & $6.07(1.54)^{* * *}$ & $7.81(2.1)^{* * *}$ & $7.42(.67)^{* * *}$ & $7.25(.71)^{* * *}$ & $8.23(.70)^{* * *}$ \\
\hline \multicolumn{6}{|l|}{ Income effects } \\
\hline Father's income & $.29(.08)^{* * *}$ & $.22(.10)^{* *}$ & $.26(.06)^{* * *}$ & & \\
\hline Parents' income & & & & $.27(.06)^{* * *}$ & $.14(.06)^{* *}$ \\
\hline $95 \% \mathrm{CI}$ & $.13, .45$ & $.03, .40$ & $.14, .39$ & $.15, .40$ & $.02, .27$ \\
\hline \multicolumn{6}{|l|}{ Parental age control } \\
\hline Father's age & $.08(.06)$ & $.00(.09)$ & - & - & - \\
\hline Father's age squared & $-.0008(.0007)$ & $.0000(.0010)$ & - & - & - \\
\hline \multicolumn{6}{|l|}{ Gender control } \\
\hline Male & - & - & $.58(.06)^{* * *}$ & $.60(.06)^{* * *}$ & $.64(.06 * * *$ \\
\hline \multicolumn{6}{|c|}{ Educational qualifications (base $=$ no school qualification) } \\
\hline School Certificate & - & - & - & - & $.17(.11)$ \\
\hline Finished high school & - & - & - & - & $.43(.09)^{* * *}$ \\
\hline Bachelor's degree & - & - & - & - & $.64(.10)^{* * *}$ \\
\hline Higher degree & - & - & - & - & $.99(.14)^{* * *}$ \\
\hline Adjusted $\mathrm{R}^{2}$ & $3.8 \%$ & $1.5 \%$ & $13 \%$ & $13 \%$ & $20 \%$ \\
\hline Probability $>$ F & 0 & .144 & 0 & 0 & 0 \\
\hline Number of cases & 393 & 372 & 780 & 764 & 763 \\
\hline
\end{tabular}

Some of the effects of parents' incomes on the incomes of their children occur because children from better-off families tend to spend longer in the education system. In model five we followed overseas studies by adding variables for participants' educational qualifications (Jo Blanden, Goodman, Gregg, \& Machin, 2004, p. 139; Ng, 2007 , p. 18). This resulted in a lower intergenerational income elasticity point estimate, with the results indicating that on average about $47 \%$ of the effects of family background on income were mediated through educational qualifications, and about $53 \%$ occurred through other channels. Calculating this effect using a series of regression equations (not shown here) produced a similar result.

We have to be cautious when trying to quantify the effects of education because qualifications and years of education are an imperfect proxy for the quality of a person's education. Using these imperfect proxies may cause the effects of educational achievement to be underestimated. However, adding additional control variables, such as physical and mental health, would probably diminish the apparent effects of education (Bowles \& Gintis, 2002, p. 5).
We also cannot tell if having high income parents in itself results in people spending longer in the education system. Further research might show that other variables, such as parental education levels and a supportive home environment, are more important (Piraino, 2007. p. 17). Parental income effects that are not mediated through educational qualifications probably result from family dynamics and parenting, the formation of preferences and aspirations, social connections, investment in other aspects of their children's lives, and genetic factors (Björklund, Jäntti, \& Solon, 2007, p. 13; Roemer, 2004, p. 51$)^{8}$

\section{The New Zealand Election Study results}

Although the Dunedin Study dataset is very comprehensive, the Study is restricted to people born within a 12 month period in a single city. Testing intergenerational occupational mobility using a national dataset that includes immigrants and people born in all regions of New Zealand provides another way of estimating intergenerational economic mobility. Election Study data on the SES of respondents and of their fathers was therefore used to calculate intergenerational 
occupational mobility. The average income of people in different occupations in the 1996 census, together with data on their educational qualifications and the value of goods they consumed, was used to calculate the SES of occupations (Davis, et al., 2003, pp. 12-16). Because of the distribution of the SES data, we were able to use it unlogged in our regression equations. The SES scores run from 10 (textile workers) to 90 (senior managers). Because of the different model specifications and units of measurement, the results are not directly comparable with those from the Dunedin Study.

Many people experiment with different jobs when entering the workforce, while young New Zealanders often travel after they finish their education. We therefore followed an overseas study by only including those who were 25 years or older (Ermisch, Francesconi, \& Siedler, 2006). Table 2 shows that the estimate for the average effect of the SES of fathers on the SES of their children was . 20 (model one). This implies that, everything else being equal, a person whose father had an SES 10 points higher than average would themselves have an SES two points higher than average as an adult. The average effect of father's SES for men was .23 (model two) and for women was similar at .18 (model three). Because of the large size of the dataset, the confidence intervals are smaller than for the Dunedin data. For instance, the confidence interval in model one for all respondents runs from .16 to .24 .

The estimated intergenerational effect of father's SES once controls for respondents' educational qualifications were added (model four) fell to just .11, which is $55 \%$ of the size of this effect before education was added. However, calculating this effect using a series of regression equations (not shown), which is a theoretically more precise way of calculating these effects, suggested that only about $35 \%$ of the intergenerational effect of father's SES occurs because children who had high SES father's tended to continue their education for longer than other children. The explanatory power of the models (as measured by the adjusted proportion of variance explained) increased to a more substantial $19 \%$ in model four, compared to a low $3.8 \%$ to $5.0 \%$ in the earlier models. We have to be extremely cautious when interpreting the results because the questions used to impute years of education resulted in considerable imprecision, while years of education are an imperfect proxy for the quality of a person's education. Using the 1993 New Zealand Election Study dataset generated similar intergenerational mobility point estimates.

Table 2: Intergenerational occupational mobility results using New Zealand Election Study survey data

\begin{tabular}{|c|c|c|c|c|}
\hline & $\begin{array}{l}\text { Model } 1 \\
\text { SES of all } \\
\text { respondents } 25 \\
\text { years or older }\end{array}$ & $\begin{array}{l}\text { Model } 2 \\
\text { SES of male } \\
\text { respondents } 25 \text { years } \\
\text { or older }\end{array}$ & $\begin{array}{l}\text { Model } 3 \\
\text { SES of female } \\
\text { respondents } 25 \\
\text { years or older }\end{array}$ & $\begin{array}{l}\text { Model } 4 \\
\text { SES of respondents } \\
25 \text { years or older } \\
\text { with education } \\
\text { controls }\end{array}$ \\
\hline Constant & $27.74(3.40)^{* * *}$ & $20.60(4.76)^{* * *}$ & $30.16(4.83)^{* * *}$ & $16.82(3.30)^{* * *}$ \\
\hline Father's SES & $.20(.02)^{* * *}$ & $.23(.02)^{* * *}$ & $.18(.03)^{* * *}$ & $.11(.02)^{* * *}$ \\
\hline $95 \%$ confidence interval & $.16, .24$ & $.18, .28$ & $.13, .23$ & $.07, .24$ \\
\hline \multicolumn{5}{|l|}{ Gender } \\
\hline Male & $3.91(.60)^{* * *}$ & - & - & $-3.26(.57)^{* * *}$ \\
\hline \multicolumn{5}{|l|}{ Age } \\
\hline Respondent's age & $.33(.14)^{* *}$ & $.51(.19)^{* * *}$ & $.17(.20)$ & $.44(.13)^{* * *}$ \\
\hline Age squared & $-.004(.001)^{* * *}$ & $-.005(.002)^{* *}$ & $-.003(.002)$ & $-.004(.001)^{* * *}$ \\
\hline \multicolumn{5}{|c|}{ Education (base=primary or none) } \\
\hline Secondary no UE & - & - & - & $4.08(1.3)^{* * *}$ \\
\hline UE & - & - & - & $10.45(1.56)^{* * *}$ \\
\hline Non-degree & - & - & - & $10.99(1.36)^{* * *}$ \\
\hline Incomplete university & - & - & - & $16.08(1.57)^{* * *}$ \\
\hline University & - & - & - & $23.99(1.51)^{* * *}$ \\
\hline Adjusted R2 & $5.0 \%$ & $4.8 \%$ & $3.8 \%$ & $19 \%$ \\
\hline Probability $>$ F & 0 & 0 & 0 & 0 \\
\hline Number of cases & 3096 & 1500 & 1596 & 3062 \\
\hline
\end{tabular}

\section{Comparing our results with those for other countries}

Now that we have tentatively estimated rates of income and occupational mobility in New Zealand we can compare our results to results from the most similar overseas studies. Considerable caution is necessary, however, because of sampling and methodological differences. Comparisons by other researchers have sometimes been criticised on the basis that differences 
may reflect methodological differences between studies rather than real differences in intergenerational mobility (Gorard, 2008, pp. 320, 322).

Table 3 compares our intergenerational income elasticity results for New Zealand men and women to those of the most similar overseas studies. To maximise comparability with the New Zealand data, we tried to find studies where children's incomes were measured once in their early thirties, and fathers' incomes had been measured twice when their children were in their teens. Although we have identified reasonably similar studies for Britain and the United States, most countries measure children's incomes their late thirties and have more income measurements than New Zealand. This may result in estimates for these countries being higher than if incomes were measured at the same age and the same number of times as in New Zealand. When people are in their late thirties, their income is more likely to be an accurate indicator of their life-time earnings. Having additional years of income data results in a more accurate picture of people's economic circumstances over time (Jäntti, et al., 2006, p. 20; Solon, 2002, pp. 61-63). However, our data may include people from a wider range of income groups than overseas studies. Most of the studies in Table 3 exclude people whose father was not working, and this may reduce the magnitude of estimates in these countries (Fortin \& Lefebvre, 1998, p. 17; Gorard, 2008, p. 320; Jäntti, et al., 2006, pp. 28-30). These and other differences in the data and in sample selection rules reduce the comparability of the Table 3 estimates (Solon, 2002, pp. 61-63).

\section{Table 3: Rates of intergenerational income mobility in New Zealand compared to those in the most similar}

studies of developed countries

\begin{tabular}{|c|c|c|c|c|c|c|c|c|}
\hline Country & Source & Sample & $\begin{array}{l}\text { Age(s) and years } \\
\text { in which income } \\
\text { was measured }\end{array}$ & $\begin{array}{l}\text { Income measure for } \\
\text { fathers or parents }\end{array}$ & \multirow{2}{*}{\multicolumn{2}{|c|}{$\begin{array}{c}5 \text { and } 95 \% \\
\text { confidence } \\
\text { intervals for } \\
\text { men } \\
.33(.27, .39)\end{array}$}} & \multicolumn{2}{|c|}{$\begin{array}{l}5 \text { and } 95 \% \\
\text { confidence } \\
\text { intervals for } \\
\text { women }\end{array}$} \\
\hline Britain & $\begin{array}{l}\text { (Jo Blanden, } \\
2008 \text {, p. 106). }\end{array}$ & $\begin{array}{l}\text { British } \\
\text { Cohort } \\
\text { Study. }\end{array}$ & 34 (2004). & Parental income 1986 & & & $43(.3$ & $.53)$ \\
\hline Canada & $\begin{array}{l}\text { (Corak, 2001, p. } \\
\text { 17) }\end{array}$ & $\begin{array}{l}\text { Statistics } \\
\text { Canada. }\end{array}$ & $32-35$ (1998). & $\begin{array}{l}\text { Fathers' earnings } \\
\text { averaged over five } \\
\text { years. }\end{array}$ & $\begin{array}{l}.262 \\
.270)\end{array}$ & $(.254$ & $\begin{array}{l}.227 \\
.235)\end{array}$ & $(.219$, \\
\hline Denmark & $\begin{array}{l}\text { (Jäntti, et al., } \\
\text { 2006, pp. 7, 13, } \\
\text { 28). Table 2. }\end{array}$ & Tax returns. & $\begin{array}{l}38-40(1998) \text { and } \\
40-42(2000) \text {. }\end{array}$ & $\begin{array}{l}\text { Fathers' earnings in } \\
1980 .\end{array}$ & $\begin{array}{l}.071 \\
.079)\end{array}$ & $(.064$ & $\begin{array}{l}.034 \\
.041)\end{array}$ & $(.027$ \\
\hline Finland & $\begin{array}{l}\text { (Jäntti, et al., } \\
\text { 2006, pp. 13, 21). } \\
\text { Table 5. }\end{array}$ & $\begin{array}{l}\text { Census and } \\
\text { tax records. }\end{array}$ & $\begin{array}{l}33-35(1993) \text { and } \\
40-42(2000) \text {. }\end{array}$ & $\begin{array}{l}\text { Fathers' earnings, } \\
1970 \text { and } 1975 .\end{array}$ & $\begin{array}{l}.213 \\
.253)\end{array}$ & $(.172$ & $\begin{array}{l}.099 \\
.137)\end{array}$ & $(.061$, \\
\hline Germany & $\begin{array}{l}\text { (Ermisch, et al., } \\
2006 \text {, pp. 666- } \\
668,673 \text { ). }\end{array}$ & $\begin{array}{l}\text { German } \\
\text { Socio- } \\
\text { Economic } \\
\text { Panel. }\end{array}$ & $\begin{array}{l}32.8 \text { (sons) and } \\
29.5 \text { (daughters); } \\
1990 \text { s on. }\end{array}$ & $\begin{array}{l}\text { Ten-year averages } \\
\text { fathers' earnings over } \\
\text { the 1984-1993 period. }\end{array}$ & $\begin{array}{l}.396 \\
.552)\end{array}$ & $(.24$, & $\begin{array}{l}.152 \\
.26)\end{array}$ & $(.044$, \\
\hline NZ & This study & $\begin{array}{l}\text { Dunedin } \\
\text { Study. }\end{array}$ & $\begin{array}{l}31-32 \\
2005) .\end{array}$ & $\begin{array}{l}\text { Parents } 1985-1986 \\
\text { and } 1987-1988 .\end{array}$ & $\begin{array}{l}.290 \\
.454)\end{array}$ & $(.127$ & $\begin{array}{l}.215 \\
.403)\end{array}$ & $(.027$, \\
\hline Norway & $\begin{array}{l}\text { (Jäntti, et al., } \\
2006 \text {, pp. 4, 13, } \\
20-21 \text { ). Table } 5 .\end{array}$ & Tax returns. & $\begin{array}{l}34(1992) \text { and } 41 \\
(1999) \text {. }\end{array}$ & $\begin{array}{l}\text { Fathers' earnings } \\
1974 \text { and other years. }\end{array}$ & $\begin{array}{l}.150 \\
.168)\end{array}$ & $(.132$ & $\begin{array}{l}.121 \\
.143)\end{array}$ & $(.099$ \\
\hline Sweden & $\begin{array}{l}\text { (Jäntti, et al., } \\
\text { 2006, pp. 7, 20- } \\
\text { 21). Table 5 }\end{array}$ & Tax returns. & $\begin{array}{l}34(1996) \text { and } 37 \\
(1999) \text {. }\end{array}$ & $\begin{array}{l}\text { Fathers' incomes, } \\
1970 \text { and } 1975 .\end{array}$ & $\begin{array}{l}.267 \\
.293)\end{array}$ & $(.241$ & $\begin{array}{l}.204 \\
.229)\end{array}$ & $(.179$, \\
\hline $\begin{array}{l}\text { United } \\
\text { States }\end{array}$ & $\begin{array}{l}\text { (Solon, 1992, p. } \\
401 \text { ) }\end{array}$ & $\begin{array}{l}\text { Panel Study } \\
\text { Income } \\
\text { Dynamics. }\end{array}$ & $25-33$ (1984). & $\begin{array}{l}\text { Fathers' earnings } \\
1967-1971 \text { (two years } \\
\text { average). }\end{array}$ & $\begin{array}{l}.290 \\
.454) \\
(.245\end{array}$ & $\begin{array}{l}(.126 \\
0.425 \\
605)\end{array}$ & Not a & ilable. \\
\hline
\end{tabular}

The confidence intervals for New Zealand are much wider than for most other countries, with this reflecting our relatively small sample size and a weak relationship (compared to other variables) between parental income and a person's own income. In many of the countries included in Table 3, the entire birth cohort for one or more years is included, provided they had positive earnings as an adult and were still living in their home country. However, our sample size and confidence intervals are similar in size to Solon's for men in the United States, and are similar to those for an early study in Britain (Atkinson, 1980; Solon, 1992, p. 401). 
The results show that our $95 \%$ confidence intervals for intergenerational income mobility in New Zealand overlap with those of most other developed countries. At a $5 \%$ level, only men in Denmark are more mobile than men from New Zealand. Comparing the results for different countries using $90 \%$ confidence intervals (not shown here) did not result in any additional differences between rates of intergenerational mobility for New Zealand men and men in other countries emerging. Even using $90 \%$ confidence intervals there were no statistically significant differences between rates of intergenerational income mobility for New Zealand women and women in other countries. Our results suggest that rates of intergenerational income mobility for New Zealand men and women are probably within a similar range to rates of intergenerational income mobility in most other developed countries.

Other researchers comparing rates of intergenerational income mobility between countries have often initially reported similarly inconclusive findings (Bjorklund \& Janntti. 1997, pp. 1016-1017: Solon. 1999, p. 1787). Greater certainty about the relative position of countries has usually resulted from applying the same methods and methodological assumptions to datasets from different countries, and by increasing the number of cases (Grawe, 2004, pp. 65-66, 70; Jäntti, et al., 2006, p. 1).

Figure 1 compares intergenerational occupational mobility in New Zealand using Election Study data to the results for Britain and Germany in a similar overseas study (Ermisch, et al.. 2006. pp. 666-669). Our results suggest that men and women in New Zealand had slightly higher intergenerational occupational mobility than people 25 years or older in Britain and that this difference was barely significant at a 10\% level. Men in New Zealand also had higher occupational mobility than men 25 years or older in Germany, and this difference was statistically significant at a $5 \%$ level. Although our point estimate for New Zealand women is lower than the point estimate for German women, even $90 \%$ confidence intervals overlapped.

Figure 1: Intergenerational occupational mobility in Britain, Germany and New Zealand

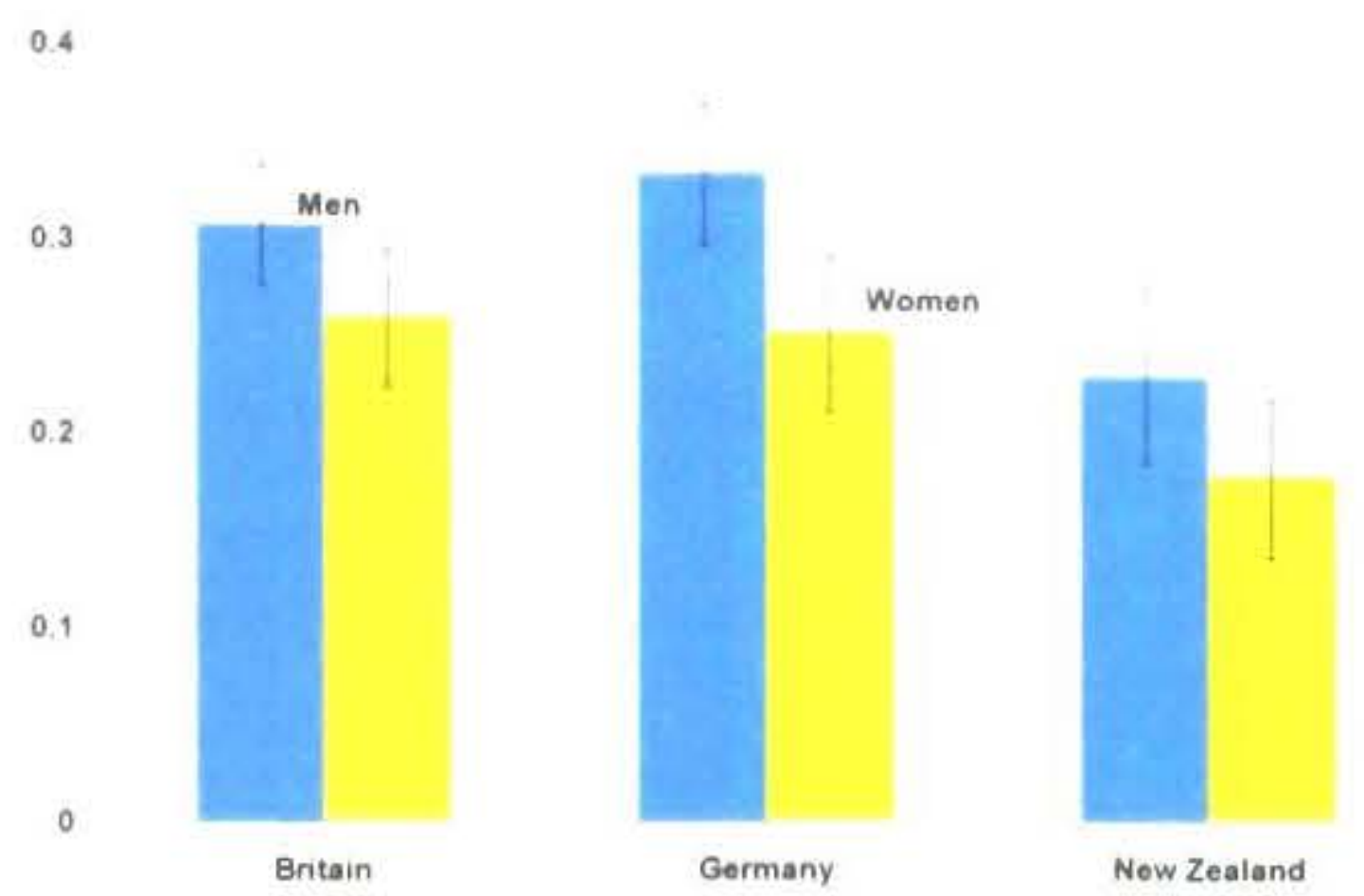

A low coefficient indicates that father's SES has a low effect on the SES of their adult children, and indicates high intergenerational occupational mobility.
In Britain and Germany, however, the standard deviations for respondents' ages suggest respondents were born within a narrower time period that in New Zealand (Ermisch, et al., 2006, p. 668). Possibly there are other methodological differences between the two studies that we are unaware of, but that affect the results. We should therefore be extremely cautious when comparing the results for New Zealand with those for Britain and Germany.

Our point estimate for New Zealand men is very similar to an unpublished intergenerational occupational mobility point estimate for New Zealand men in an overseas study. Although the results of that study suggested that New Zealand had high intergenerational occupational mobility compared to other countries, with New Zealand placed third out of 32 countries, unfortunately confidence intervals were not included (Jo Blanden, 2008, p. 34).

\section{Conclusion}

This paper has been the first in-depth research since the 1980 s into intergenerational economic mobility in New Zealand. Our research has been exploratory and our findings are very tentative.

Using data from the Dunedin Study, our model estimated an intergenerational income elasticity of .26 with $95 \%$ confidence intervals of .14 and .39 . This implies that a $1 \%$ increase in father's income is associated with a $0.26 \%$ increase in the income of an individual at age 32 , with this estimate consistent with being between $0.14 \%$ and $0.39 \%$ with $95 \%$ confidence. Using combined parents' income, rather than father's income, as the main explanatory variable had very little effect on the results. The childhood income of a person's parents seems to explain only a small proportion of the variance in their adult income. We were unable to reach firm conclusions about the rate of intergenerational income mobility in New Zealand compared to most other developed countries, with the confidence intervals for our point estimates overlapping with the confidence intervals for almost all other developed countries.

We also used occupation data from the nation-wide 1996 Election Study to see what effect the SES of a person's father had on their own SES when they were grown up. When the Election Study analysis was restricted to people aged 25 or over the effect of father's SES on the SES of their children was .20 in 1996, with $95 \%$ confidence intervals of .16 and .24 , although only a small proportion of the variance in people's SES was explained. There was weak evidence that intergenerational occupational mobility for New Zealanders was higher than for people in Britain, and stronger evidence that New Zealand men were more intergenerationally occupationally mobile than German men. Insufficient data is available to reach conclusions about intergenerational occupational mobility in New Zealand compared to other countries.

Our results suggest that in New Zealand some of the effect of parents' income or father's SES on the economic outcomes of their children occurs because children from 
better-off families tend to spend longer in the education system. Our estimate for this proportion using Dunedin Study data was just under half, while our best estimate using the Election Study data was about a third. These are very approximate proportions, and adding additional variables to our models would reduce these effects (Bowles \& Gintis, 2002, p. 22).

It should be emphasised that our findings are very preliminary. When Dunedin Study participants are in their late thirties they are more likely to be in their peak earning years. Using data from the planned 2010-2011 assessments should result in more accurate, but still imperfect, estimates of intergenerational income mobility (Haider \& Solon, 2006, p. 1317). Future researchers could increase the number of cases that can be included in the Dunedin Study models by imputing missing income data for participants' parents from information on their occupation, education, age, and employment status. In addition, calculating an income for each parent in the top income group from other data might produce a more sophisticated picture of the economic circumstances of some families. Possibly other datasets containing the incomes of New Zealand children and of their parents could be developed. In 2008 the New Zealand Election Study asked about the occupations of respondents' parents for the first time since 1996, and this data could be used to update our research into intergenerational occupational mobility.

\section{Notes}

1. Treasury plans to publish fuller details of our intergenerational mobility findings at a later date.

2. The Pearson's correlation shows the strength of linear dependence between two variables and gives a value between -1 and 1 .

3. http://www.nzes.org/exec/show/1996

4. The correlation between Election Study income results and SES is only .32, although the eight income bands the Election Study used are not ideally designed for the comparison. In contrast, for the Dunedin Study participants the relationship between SES and income is . 45

5. Restricting the analysis to just those living in New Zealand (results not shown here) produced broadly similar point estimates.

6. In this example the only requirement is that these men have the same aged father. The model does not control for the effects of other characteristics. The elasticity is for the effect of the log of fathers' incomes on the log of sons' incomes. To calculate an estimated income it is necessary to multiply the log of father's income by the elasticity, multiply the father's age and age squared by the coefficients for these variables, add the intercept, then take an anti-log.
7. However, when we drop the age variables the model just crosses the threshold for being statistically significant.

8. In addition, we only have data on five stages of educational achievement, rather than the exact number of years participants spent in the education system. However, rerunning the models using a variable for self-reported months of education between 15 and 21 had only a slight effect on the results.

\section{References}

Andrews, D., \& Leigh, A. (2008). More inequality, less social mobility (Discussion Paper). Canberra: ANU.

Atkinson, A. B. (1980). On intergenerational income mobility in Britain. Journal of Post Keynesian Economics, 3(2), 194.

Bjorklund, A., \& Janntti, M. (1997). Intergenerational income mobility in Sweden compared to the United States. The American Economic Review; 87(5), 1009-1018.

Björklund, A., Jäntti, M., \& Solon, G. (2007). Nature and Nurture in the Intergenerational Transmission of Socioeconomic Status: Evidence from Swedish Children and Their Biological and Rearing Parents. The B.E. Journal of Economic Analysis \& Policy, 7(2).

Blanden, J. (2008). How much can we learn from international comparisons of social mobility? : Department of Economics, University of Surrey.

Blanden, J., Goodman, A., Gregg, P., \& Machin, S. (2004). Changes in intergenerational mobility in Britain. In M. Corak (Ed.), Generational Income Mobility in North America and Europe (pp. 122146). Cambridge: Cambridge University Press.

Blanden, J., Gregg, P., \& Machin, S. (2005). Intergenerational mobility in Europe and North America. London: Centre for Economic Performance.

Blanden, J., \& Machin, S. (2007). Recent changes in intergenerational mobility in Britain (Report for Sutton Trust). London.

Bowles, S., \& Gintis, H. (2002). The Inheritance of Inequality. The Journal of Economic Perspectives, 16(3), 3-30.

Corak, M. (2001). Are the Kids All Right? Intergenerational Mobility and Child Well-being in Canada. Ottawa: Statistics Canada, Analytical Studies Branch. 
Corak, M. (2006). Do poor children become poor adults? Lessons from a cross country comparison of generational earnings mobility. Bonn, Germany: IZA.

d'Addio, A. C. (2007). Intergenerational transmission of disadvantage: Mobility or immobility across generations? A review of the evidence for $O E C D$ countries. Paris: OECD.

Davis, P., Jenkin, G., \& Coope, P. (2003). New Zealand socio-economic Index 1996: An update and revision of the New Zealand socio-economic index of occupational status. Wellington: Statistics New Zealand.

Electoral Law Committee (1998). Interim report on the inquiry into the 1996 General Election Appendices to the Journals of the House of Representatives. Wellington: House of Representatives.

Ermisch, J., Francesconi, M., \& Siedler, T. (2006). Intergenerational mobility and marital sorting. The Economic Journal, 116(513), 659-679.

Fortin, N. B., \& Lefebvre, S. (1998). Intergenerational income mobility in Canada. In M. Corak (Ed.), Labour Markets, Social Institutions and the Future of Canada's Children. Ottawa: Statistics Canada.

Gorard, S. (2008). A re-consideration of rates of 'social mobility' in Britain: or why research impact is not always a good thing. British Journal of Sociology of Education, 29(3), 317 - 324.

Grawe, N. D. (2004). Intergenerational mobility for whom? The experience of high- and low-earning sons in international perspective. In M. Corak (Ed.), Generational income mobility in North America and Europe (pp. 58-89). Cambridge: Cambridge University Press.

Haider, S., \& Solon, G. (2006). Life-cycle variation in the association between current and lifetime earnings, American Economic Review (Vol. 96, pp. 1308-1320): American Economic Association.

Jäntti, M., Bratsberg, B., Røed, K., Rauum, O., Naylor, R., Österbacka , E., et al. (2006). American exceptionalism in a new light: $A$ comparison of intergenerational earnings mobility in the Nordic Countries, the United Kingdom and the United States, Bonn: IZA.

Melchior, M., Moffitt, T. E., Milne, B. J., Poulton, R., \& Caspi, A. (2007). Why do children from socioeconomically disadvantaged families suffer from poor health when they reach adulthood? A life-course study. American Journal of Epidemiology, 166(8), 966-974.
New Zealand Post (1997). New Zealand Post Annual Report. Wellington.

$\mathrm{Ng}$, I. (2007). Intergenerational Income Mobility in Singapore. B.E. Journal of Economic Analysis \& Policy, 7(2).

OECD (2008). Working Paper No. 1 on macroeconomic and structural policy analysis. Paris: OECD.

Piraino, P. (2007). Comparable estimates of intergenerational income mobility in Italy. Berkeley Electronic Press 7(2), 17-11.

Poulton, R., Hancox, R., Milne, B., Baxter, J., Scott, K., \& Wilson, N. (2006). The Dunedin Multidisciplinary Health and Development Study: are its findings consistent with the overall New Zealand population? The New Zealand Medical Journal, 119(1235), 1-11.

Roemer, J. E. (2004). Equal opportunity and intergenerational mobility: going beyond intergenerational income transition matrices. In $\mathrm{M}$. Corak (Ed.), Generational income mobility in North America and Europe (pp. 48-57). Cambridge: Cambridge University Press.

Silva, P. A., \& McCann, M. (1996). Introduction to the Dunedin Study. In P. A. Silva \& W. R. Stanton (Eds.), From child to adult: The Dunedin Multidisciplinary Health and Development Study (pp. 1-24). Auckland: Oxford University Press.

Solon, G. (1992). Intergenerational Income Mobility in the United States American Economic Review, $82(3)$.

Solon, G. (1999). Intergenerational mobility in the labor market. In O. C. Ashenfelter \& D. Card (Eds.), Handbook of Labor Economics (Vol. Volume 3, Part 1, pp. 1761-1800): Elsevier.

Solon, G. (2002). Cross-Country Differences in Intergenerational Earnings Mobility Journal of Economic Perspectives, 16(3), 59-66.

Vowles, J. (2002). The puzzle of turnout. In J. Vowles, P. Aimer, S. Banducci, R. Miller \& A. Sullivan (Eds.), Proportional representation on trial: The 1999 General Election and the fate of MMP. Auckland: Auckland University Press.

\section{Author}

Matthew Gibbons

New Zealand Treasury

P.O. Box 3724

Wellington 6140

Matthew.Gibbons@treasury.govt.nz 